\title{
Impact of online classes on the satisfaction and performance of students during the pandemic period of COVID 19
}

\author{
Ram Gopal $^{1} \cdot$ Varsha Singh $^{1} \cdot$ Arun Aggarwal $^{2} \mathbb{D}$
}

Received: 7 December 2020 / Accepted: 22 March 2021 / Published online: 21 April 2021

(C) The Author(s), under exclusive licence to Springer Science+Business Media, LLC, part of Springer Nature 2021

\begin{abstract}
The aim of the study is to identify the factors affecting students' satisfaction and performance regarding online classes during the pandemic period of COVID-19 and to establish the relationship between these variables. The study is quantitative in nature, and the data were collected from 544 respondents through online survey who were studying the business management (B.B.A or M.B.A) or hotel management courses in Indian universities. Structural equation modeling was used to analyze the proposed hypotheses. The results show that four independent factors used in the study viz. quality of instructor, course design, prompt feedback, and expectation of students positively impact students' satisfaction and further student's satisfaction positively impact students' performance. For educational management, these four factors are essential to have a high level of satisfaction and performance for online courses. This study is being conducted during the epidemic period of COVID- 19 to check the effect of online teaching on students' performance.
\end{abstract}

Keywords COVID-19 - Quality of instructor · Course design · Instructor's prompt feedback · Expectations · Student's satisfaction $\cdot$ Perceived performance

Arun Aggarwal

arunaggarwal.mba@gmail.com

Ram Gopal

ram.gopal@chitkara.edu.in

Varsha Singh

varsha.s@chitkara.edu.in

1 Chitkara College of Hospitality Management, Chitkara University, Chandigarh, Punjab, India

2 Chitkara Business School, Chitkara University, Chandigarh, Punjab, India 


\section{Introduction}

Coronavirus is a group of viruses that is the main root of diseases like cough, cold, sneezing, fever, and some respiratory symptoms (WHO, 2019). Coronavirus is a contagious disease, which is spreading very fast amongst the human beings. COVID-19 is a new sprain which was originated in Wuhan, China, in December 2019. Coronavirus circulates in animals, but some of these viruses can transmit between animals and humans (Perlman \& Mclntosh, 2020). As of March 282,020, according to the MoHFW, a total of 909 confirmed COVID-19 cases (862 Indians and 47 foreign nationals) had been reported in India (Centers for Disease Control and Prevention, 2020). Officially, no vaccine or medicine is evaluated to cure the spread of COVID-19 (Yu et al., 2020). The influence of the COVID-19 pandemic on the education system leads to schools and colleges' widespread closures worldwide. On March 24, India declared a country-wide lockdown of schools and colleges (NDTV, 2020) for preventing the transmission of the coronavirus amongst the students (Bayham \& Fenichel, 2020). School closures in response to the COVID-19 pandemic have shed light on several issues affecting access to education. COVID19 is soaring due to which the huge number of children, adults, and youths cannot attend schools and colleges (UNESCO, 2020). Lah and Botelho (2012) contended that the effect of school closing on students' performance is hazy.

Similarly, school closing may also affect students because of disruption of teacher and students' networks, leading to poor performance. Bridge (2020) reported that schools and colleges are moving towards educational technologies for student learning to avoid a strain during the pandemic season. Hence, the present study's objective is to develop and test a conceptual model of student's satisfaction pertaining to online teaching during COVID-19, where both students and teachers have no other option than to use the online platform uninterrupted learning and teaching.

UNESCO recommends distance learning programs and open educational applications during school closure caused by COVID-19 so that schools and teachers use to teach their pupils and bound the interruption of education. Therefore, many institutes go for the online classes (Shehzadi et al., 2020).

As a versatile platform for learning and teaching processes, the E-learning framework has been increasingly used (Salloum \& Shaalan, 2018). E-learning is defined as a new paradigm of online learning based on information technology (Moore et al., 2011). In contrast to traditional learning academics, educators, and other practitioners are eager to know how e-learning can produce better outcomes and academic achievements. Only by analyzing student satisfaction and their performance can the answer be sought.

Many comparative studies have been carried out to prove the point to explore whether face-to-face or traditional teaching methods are more productive or whether online or hybrid learning is better (Lockman \& Schirmer, 2020; Pei \& Wu, 2019; González-Gómez et al., 2016; González-Gómez et al., 2016). Results of the studies show that the students perform much better in online learning than in traditional learning. Henriksen et al. (2020) highlighted the problems faced by educators while shifting from offline to online mode of teaching. In the past, 
several research studies had been carried out on online learning to explore student satisfaction, acceptance of e-learning, distance learning success factors, and learning efficiency (Sher, 2009; Lee, 2014; Yen et al., 2018). However, scant amount of literature is available on the factors that affect the students' satisfaction and performance in online classes during the pandemic of Covid-19 (Rajabalee \& Santally, 2020). In the present study, the authors proposed that course design, quality of the instructor, prompt feedback, and students' expectations are the four prominent determinants of learning outcome and satisfaction of the students during online classes (Lee, 2014).

The Course Design refers to curriculum knowledge, program organization, instructional goals, and course structure (Wright, 2003). If well planned, course design increasing the satisfaction of pupils with the system (Almaiah \& Alyoussef, 2019). Mtebe and Raisamo (2014) proposed that effective course design will help in improving the performance through learners knowledge and skills (Khan \& Yildiz, 2020; Mohammed et al., 2020). However, if the course is not designed effectively then it might lead to low usage of e-learning platforms by the teachers and students (Almaiah \& Almulhem, 2018). On the other hand, if the course is designed effectively then it will lead to higher acceptance of e-learning system by the students and their performance also increases (Mtebe \& Raisamo, 2014). Hence, to prepare these courses for online learning, many instructors who are teaching blended courses for the first time are likely to require a complete overhaul of their courses (Bersin, 2004; Ho et al., 2006).

The second-factor, Instructor Quality, plays an essential role in affecting the students' satisfaction in online classes. Instructor quality refers to a professional who understands the students' educational needs, has unique teaching skills, and understands how to meet the students' learning needs (Luekens et al., 2004). Marsh (1987) developed five instruments for measuring the instructor's quality, in which the main method was Students' Evaluation of Educational Quality (SEEQ), which delineated the instructor's quality. SEEQ is considered one of the methods most commonly used and embraced unanimously (Grammatikopoulos et al., 2014). SEEQ was a very useful method of feedback by students to measure the instructor's quality (Marsh, 1987).

The third factor that improves the student's satisfaction level is prompt feedback (Kinicki et al., 2004). Feedback is defined as information given by lecturers and tutors about the performance of students. Within this context, feedback is a "consequence of performance" (Hattie \& Timperley, 2007, p. 81). In education, "prompt feedback can be described as knowing what you know and what you do not related to learning" (Simsek et al., 2017, p.334). Christensen (2014) studied linking feedback to performance and introduced the positivity ratio concept, which is a mechanism that plays an important role in finding out the performance through feedback. It has been found that prompt feedback helps in developing a strong linkage between faculty and students which ultimately leads to better learning outcomes (Simsek et al., 2017; Chang, 2011).

The fourth factor is students' expectation. Appleton-Knapp and Krentler (2006) measured the impact of student's expectations on their performance. They pin pointed that the student expectation is important. When the expectations of the students are achieved then it lead to the higher satisfaction level of the student (Bates 
\& Kaye, 2014). These findings were backed by previous research model "Student Satisfaction Index Model" (Zhang et al., 2008). However, when the expectations are students is not fulfilled then it might lead to lower leaning and satisfaction with the course. Student satisfaction is defined as students' ability to compare the desired benefit with the observed effect of a particular product or service (Budur et al., 2019). Students' whose grade expectation is high will show high satisfaction instead of those facing lower grade expectations.

The scrutiny of the literature show that although different researchers have examined the factors affecting student satisfaction but none of the study has examined the effect of course design, quality of the instructor, prompt feedback, and students' expectations on students' satisfaction with online classes during the pandemic period of Covid-19. Therefore, this study tries to explore the factors that affect students' satisfaction and performance regarding online classes during the pandemic period of COVID-19. As the pandemic compelled educational institutions to move online with which they were not acquainted, including teachers and learners. The students were not mentally prepared for such a shift. Therefore, this research will be examined to understand what factors affect students and how students perceived these changes which are reflected through their satisfaction level.

This paper is structured as follows: The second section provides a description of theoretical framework and the linkage among different research variables and accordingly different research hypotheses were framed. The third section deals with the research methodology of the paper as per APA guideline. The outcomes and corresponding results of the empirical analysis are then discussed. Lastly, the paper concludes with a discussion and proposes implications for future studies.

\section{Theoretical framework}

Achievement goal theory (AGT) is commonly used to understand the student's performance, and it is proposed by four scholars Carole Ames, Carol Dweck, Martin Maehr, and John Nicholls in the late 1970s (Elliot, 2005). Elliott \& Dweck (1988, p11) define that "an achievement goal involves a program of cognitive processes that have cognitive, affective and behavioral consequence". This theory suggests that students' motivation and achievement-related behaviors can be easily understood by the purpose and the reasons they adopted while they are engaged in the learning activities (Dweck \& Leggett, 1988; Ames, 1992; Urdan, 1997). Some of the studies believe that there are four approaches to achieve a goal, i.e., mastery-approach, mastery avoidance, performance approach, and performance-avoidance (Pintrich, 1999; Elliot \& McGregor, 2001; Schwinger \& Stiensmeier-Pelster, 2011, Hansen \& Ringdal, 2018; Mouratidis et al., 2018). The environment also affects the performance of students (Ames \& Archer, 1988). Traditionally, classroom teaching is an effective method to achieve the goal (Ames \& Archer, 1988; Ames, 1992; Clayton et al., 2010) however in the modern era, the internet-based teaching is also one of the effective tools to deliver lectures, and web-based applications are becoming modern classrooms (Azlan et al., 2020). Hence, following section discuss about the relationship between different independent variables and dependent variables (Fig. 1). 


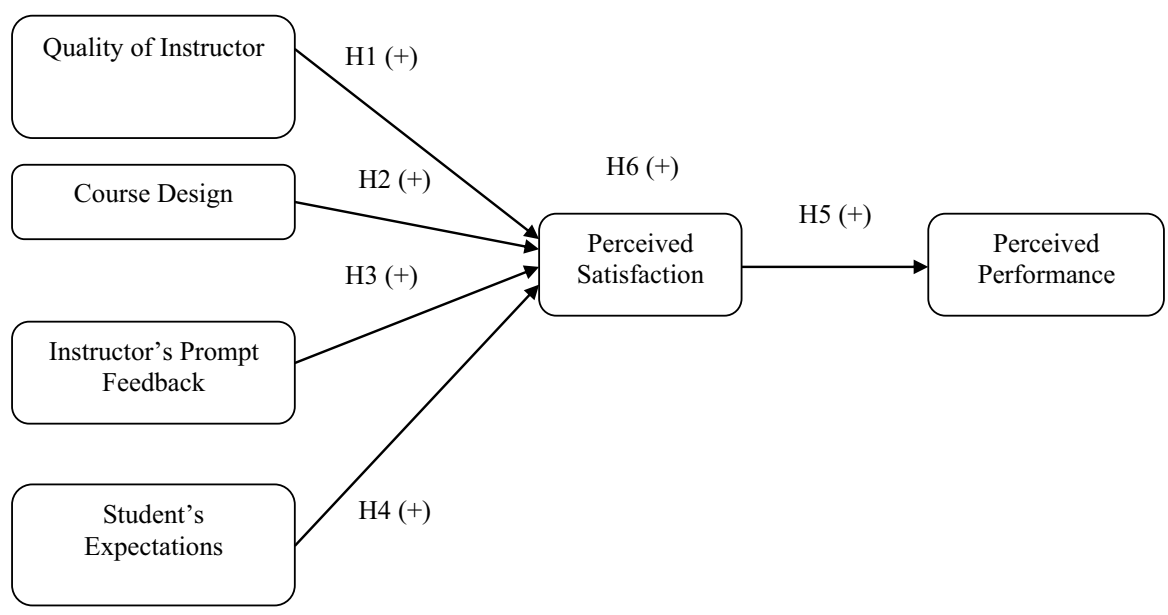

Fig. 1 Proposed Model

\section{Hypotheses development}

\subsection{Quality of the instructor and satisfaction of the students}

Quality of instructor with high fanaticism on student's learning has a positive impact on their satisfaction. Quality of instructor is one of the most critical measures for student satisfaction, leading to the education process's outcome (Munteanu et al., 2010; Arambewela \& Hall, 2009; Ramsden, 1991). Suppose the teacher delivers the course effectively and influence the students to do better in their studies. In that case, this process leads to student satisfaction and enhances the learning process (Ladyshewsky, 2013). Furthermore, understanding the need of learner by the instructor also ensures student satisfaction (Kauffman, 2015). Hence the hypothesis that the quality of instructor significantly affects the satisfaction of the students was included in this study.

H1: The quality of the instructor positively affects the satisfaction of the students.

\subsection{Course design and satisfaction of students}

The course's technological design is highly persuading the students' learning and satisfaction through their course expectations (Liaw, 2008; Lin et al., 2008). Active course design indicates the students' effective outcomes compared to the traditional design (Black \& Kassaye, 2014). Learning style is essential for effective course design (Wooldridge, 1995). While creating an online course design, it is essential to keep in mind that we generate an experience for students with different learning styles. Similarly, (Jenkins, 2015) highlighted that the course design attributes could be developed and employed to enhance student success. Hence the hypothesis that the course design significantly affects students' satisfaction was included in this study.

$\mathrm{H} 2$ : Course design positively affects the satisfaction of students. 


\subsection{Prompt feedback and satisfaction of students}

The emphasis in this study is to understand the influence of prompt feedback on satisfaction. Feedback gives the information about the students' effective performance (Chang, 2011; Grebennikov \& Shah, 2013; Simsek et al., 2017). Prompt feedback enhances student learning experience (Brownlee et al., 2009) and boosts satisfaction (O'donovan, 2017). Prompt feedback is the self-evaluation tool for the students (Rogers, 1992) by which they can improve their performance. Eraut (2006) highlighted the impact of feedback on future practice and student learning development. Good feedback practice is beneficial for student learning and teachers to improve students' learning experience (Yorke, 2003). Hence the hypothesis that prompt feedback significantly affects satisfaction was included in this study.

H3: Prompt feedback of the students positively affects the satisfaction.

\subsection{Expectations and satisfaction of students}

Expectation is a crucial factor that directly influences the satisfaction of the student. Expectation Disconfirmation Theory (EDT) (Oliver, 1980) was utilized to determine the level of satisfaction based on their expectations (Schwarz \& Zhu, 2015). Student's expectation is the best way to improve their satisfaction (Brown et al., 2014). It is possible to recognize student expectations to progress satisfaction level (ICSB, 2015). Finally, the positive approach used in many online learning classes has been shown to place a high expectation on learners (Gold, 2011) and has led to successful outcomes. Hence the hypothesis that expectations of the student significantly affect the satisfaction was included in this study.

H4: Expectations of the students positively affects the satisfaction.

\subsection{Satisfaction and performance of the students}

Zeithaml (1988) describes that satisfaction is the outcome result of the performance of any educational institute. According to Kotler and Clarke (1986), satisfaction is the desired outcome of any aim that amuses any individual's admiration. Quality interactions between instructor and students lead to student satisfaction (Malik et al., 2010; Martínez-Argüelles et al., 2016). Teaching quality and course material enhances the student satisfaction by successful outcomes (Sanderson, 1995). Satisfaction relates to the student performance in terms of motivation, learning, assurance, and retention (Biner et al., 1996). Mensink and King (2020) described that performance is the conclusion of student-teacher efforts, and it shows the interest of students in the studies. The critical element in education is students' academic performance (Rono, 2013). Therefore, it is considered as center pole, and the entire education system rotates around the student's performance. Narad and Abdullah (2016) concluded that the students' academic performance determines academic institutions' success and failure.

Singh et al. (2016) asserted that the student academic performance directly influences the country's socio-economic development. Farooq et al. (2011) highlights the students' academic performance is the primary concern of all faculties. Additionally, 
the main foundation of knowledge gaining and improvement of skills is student's academic performance. According to Narad and Abdullah (2016), regular evaluation or examinations is essential over a specific period of time in assessing students' academic performance for better outcomes. Hence the hypothesis that satisfaction significantly affects the performance of the students was included in this study.

H5: Students' satisfaction positively affects the performance of the students.

\subsection{Satisfaction as mediator}

Sibanda et al. (2015) applied the goal theory to examine the factors persuading students' academic performance that enlightens students' significance connected to their satisfaction and academic achievement. According to this theory, students perform well if they know about factors that impact on their performance. Regarding the above variables, institutional factors that influence student satisfaction through performance include course design and quality of the instructor (DeBourgh, 2003; Lado et al., 2003), prompt feedback, and expectation (Fredericksen et al., 2000). Hence the hypothesis that quality of the instructor, course design, prompts feedback, and student expectations significantly affect the students' performance through satisfaction was included in this study.

H6: Quality of the instructor, course design, prompt feedback, and student' expectations affect the students' performance through satisfaction.

H6a: Students' satisfaction mediates the relationship between quality of the instructor and student's performance.

H6b: Students' satisfaction mediates the relationship between course design and student's performance.

H6c: Students' satisfaction mediates the relationship between prompt feedback and student's performance.

H6d: Students' satisfaction mediates the relationship between student' expectations and student's performance.

\section{Method}

\subsection{Participants}

In this cross-sectional study, the data were collected from 544 respondents who were studying the management (B.B.A or M.B.A) and hotel management courses. The purposive sampling technique was used to collect the data. Descriptive statistics shows that $48.35 \%$ of the respondents were either MBA or BBA and rests of the respondents were hotel management students. The percentages of male students were (71\%) and female students were (29\%). The percentage of male students is almost double in comparison to females. The ages of the students varied from 18 to 35 . The dominant group was those aged from 18 to 22 , and which was the under graduation student group and their ratio was (94\%), and another set of students were from the post-graduation course, which was (6\%) only. 


\subsection{Materials}

The research instrument consists of two sections. The first section is related to demographical variables such as discipline, gender, age group, and education level (undergraduate or post-graduate). The second section measures the six factors viz. instructor's quality, course design, prompt feedback, student expectations, satisfaction, and performance. These attributes were taken from previous studies (Yin \& Wang, 2015; Bangert, 2004; Chickering \& Gamson, 1987; Wilson et al., 1997). The "instructor quality" was measured through the scale developed by Bangert (2004). The scale consists of seven items. The "course design" and "prompt feedback" items were adapted from the research work of Bangert (2004). The "course design" scale consists of six items. The "prompt feedback" scale consists of five items. The "students' expectation" scale consists of five items. Four items were adapted from Bangert, 2004 and one item was taken from Wilson et al. (1997). Students' satisfaction was measure with six items taken from Bangert (2004); Wilson et al. (1997); Yin and Wang (2015). The "students' performance" was measured through the scale developed by Wilson et al. (1997). The scale consists of six items. These variables were accessed on a five-point likert scale, ranging from 1(strongly disagree) to 5(strongly agree). Only the students from India have taken part in the survey. A total of thirty-four questions were asked in the study to check the effect of the first four variables on students' satisfaction and performance. For full details of the questionnaire, kindly refer Appendix Tables 6.

\subsection{Design}

The study used a descriptive research design. The factors "instructor quality, course design, prompt feedback and students' expectation” were independent variables. The students' satisfaction was mediator and students' performance was the dependent variable in the current study.

\subsection{Procedure}

In this cross-sectional research the respondents were selected through judgment sampling. They were informed about the objective of the study and information gathering process. They were assured about the confidentiality of the data and no incentive was given to then for participating in this study. The information utilizes for this study was gathered through an online survey. The questionnaire was built through Google forms, and then it was circulated through the mails. Students' were also asked to write the name of their college, and fifteen colleges across India have taken part to fill the data. The data were collected in the pandemic period of COVID-19 during the total lockdown in India. This was the best time to collect the data related to the current research topic because all the colleges across India were involved in online classes. Therefore, students have enough time to understand the instrument and respondent to the questionnaire in an effective manner. A total of 615 questionnaires were circulated, out of which the students returned 574. Thirty responses were not included due to the unengaged responses. Finally, 544 
questionnaires were utilized in the present investigation. Male and female students both have taken part to fill the survey, different age groups, and various courses, i.e., under graduation and post-graduation students of management and hotel management students were the part of the sample.

\section{Results}

\subsection{Exploratory factor analysis (EFA)}

To analyze the data, SPSS and AMOS software were used. First, to extract the distinct factors, an exploratory factor analysis (EFA) was performed using VARIMAX rotation on a sample of 544. Results of the exploratory analysis rendered six distinct factors. Factor one was named as the quality of instructor, and some of the items were "The instructor communicated effectively", "The instructor was enthusiastic about online teaching" and "The instructor was concerned about student learning" etc. Factor two was labeled as course design, and the items were "The course was well organized", "The course was designed to allow assignments to be completed across different learning environments." and "The instructor facilitated the course effectively" etc. Factor three was labeled as prompt feedback of students, and some of the items were "The instructor responded promptly to my questions about the use of Webinar", "The instructor responded promptly to my questions about general course requirements" etc. The fourth factor was Student's Expectations, and the items were "The instructor provided models that clearly communicated expectations for weekly group assignments", "The instructor used good examples to explain statistical concepts" etc. The fifth factor was students' satisfaction, and the items were "The online classes were valuable", "Overall, I am satisfied with the quality of this course" etc. The sixth factor was performance of the student, and the items were "The online classes has sharpened my analytic skills", "Online classes really tries to get the best out of all its students" etc. These six factors explained $67.784 \%$ of the total variance. To validate the factors extracted through EFA, the researcher performed confirmatory factor analysis (CFA) through AMOS. Finally, structural equation modeling (SEM) was used to test the hypothesized relationships.

\subsection{Measurement model}

The results of Table 1 summarize the findings of EFA and CFA. Results of the table showed that EFA renders six distinct factors, and CFA validated these factors. Table 2 shows that the proposed measurement model achieved good convergent validity (Aggarwal et al., 2018a, b). Results of the confirmatory factor analysis showed that the values of standardized factor loadings were statistically significant at the 0.05 level. Further, the results of the measurement model also showed acceptable model fit indices such that $\mathrm{CMIN}=710.709 ; \mathrm{df}=480 ; \mathrm{CMIN} / \mathrm{df}=1.481 p<.000$; Incremental Fit Index (IFI) $=0.979$; Tucker-Lewis Index $(\mathrm{TLI})=0.976$; Goodness of Fit index $(\mathrm{GFI})=0.928$; Adjusted Goodness of Fit Index $(\mathrm{AGFI})=0.916$; 


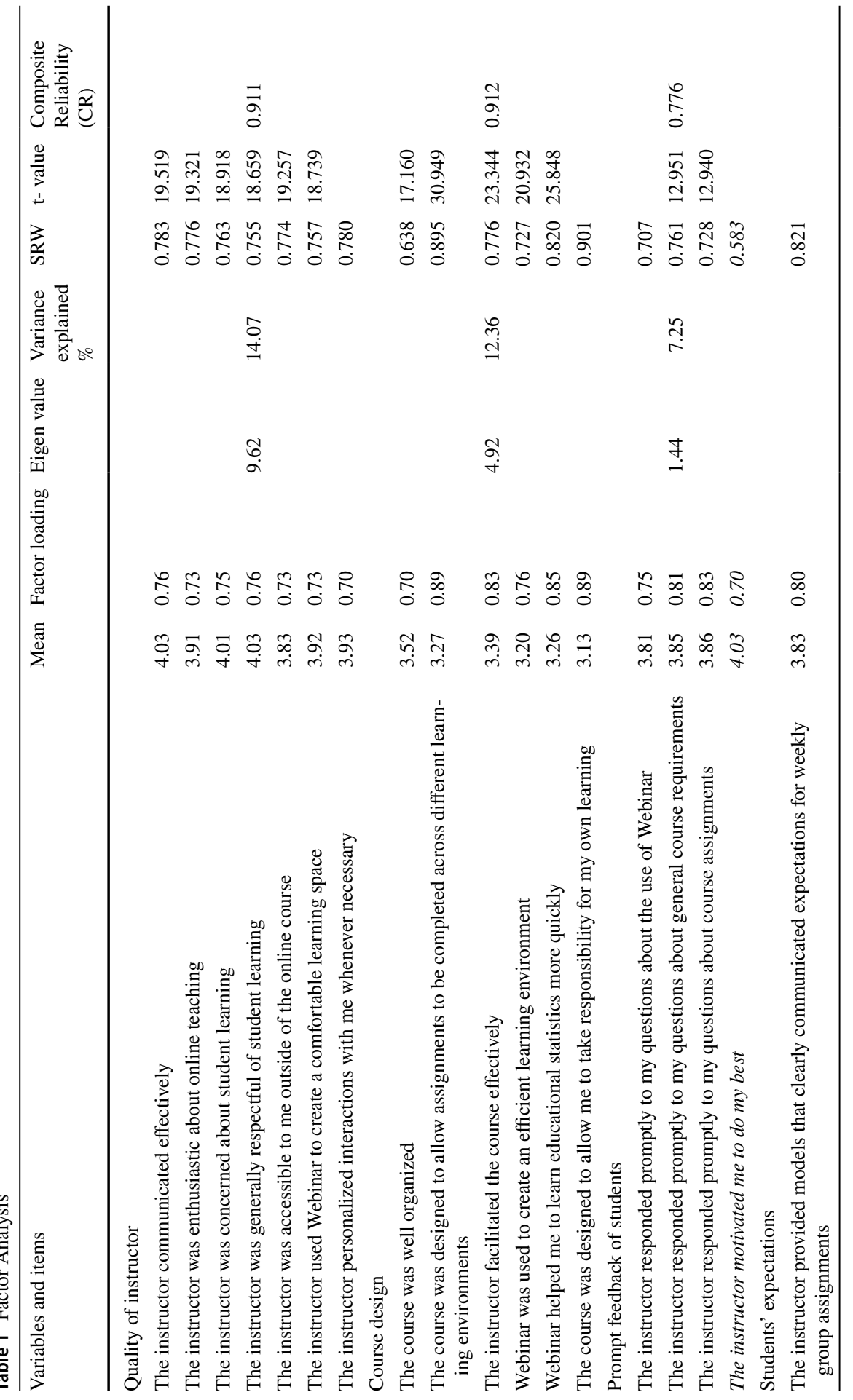




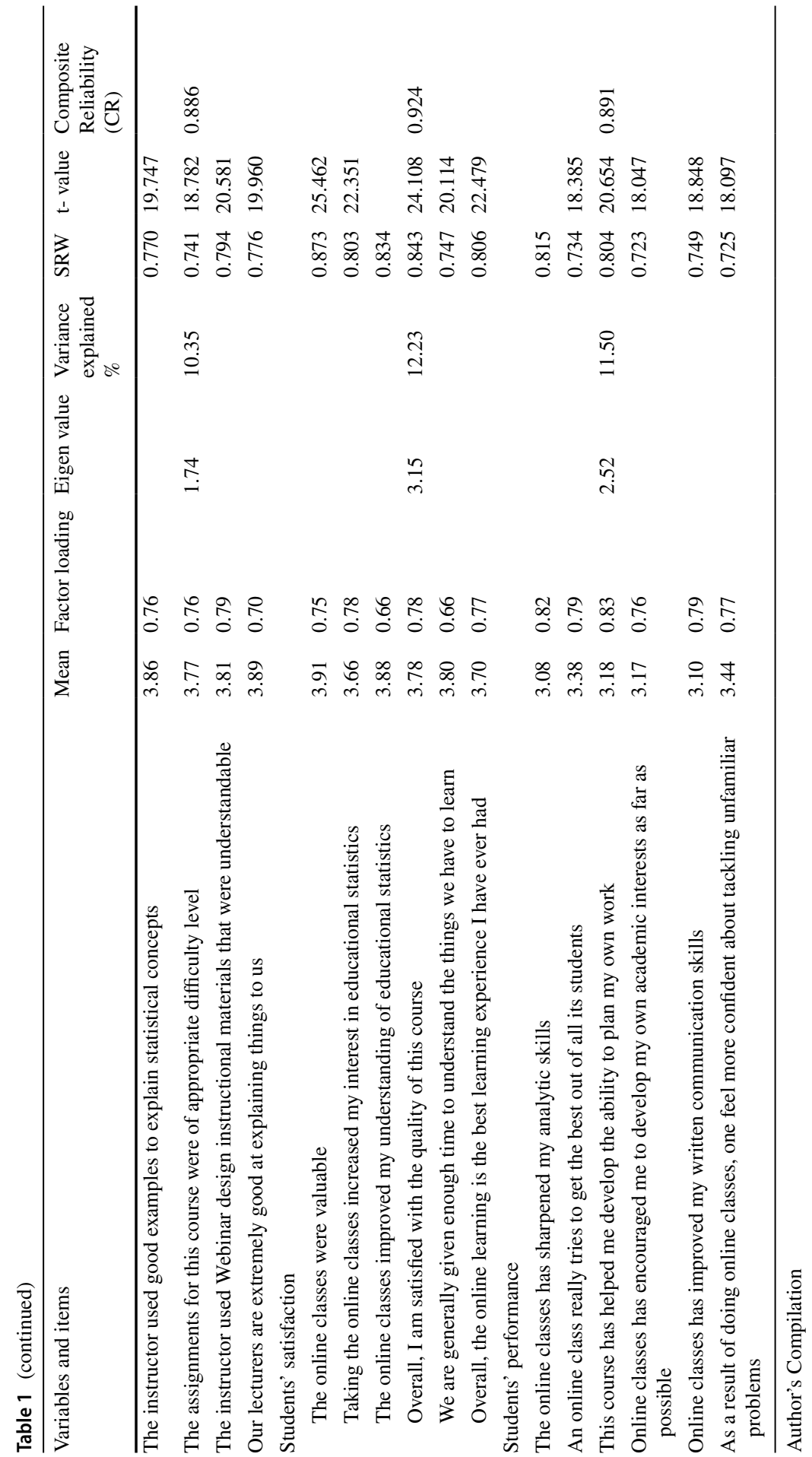


Table 2 Validity analysis of measurement model

\begin{tabular}{lllllllll}
\hline & CR & AVE & 1 & 2 & 3 & 4 & 5 & 6 \\
\hline Satisfaction & 0.924 & 0.670 & $\mathbf{0 . 8 1 9}$ & & & & & \\
Quality & 0.911 & 0.593 & 0.740 & $\mathbf{0 . 7 7 0}$ & & & & \\
Design & 0.912 & 0.637 & 0.070 & 0.125 & $\mathbf{0 . 7 9 8}$ & & & \\
Feedback & 0.776 & 0.536 & 0.015 & 0.044 & 0.026 & $\mathbf{0 . 7 3 2}$ & & \\
Expectation & 0.886 & 0.610 & 0.615 & 0.615 & 0.001 & 0.071 & $\mathbf{0 . 7 8 1}$ & $\mathbf{0 . 7 5 9}$ \\
Performance & 0.891 & 0.576 & 0.137 & 0.042 & 0.242 & -0.020 & 0.027 & \\
\hline
\end{tabular}

Author's compilation

AVE is the Average Variance Extracted, CR is Composite Reliability

The bold diagonal value represents the square root of AVE

Comparative Fit Index $(\mathrm{CFI})=0.978$; Root Mean Square Residual $(\mathrm{RMR})=0.042$; Root Mean Squared Error of Approximation (RMSEA) $=0.030$ is satisfactory.

The Average Variance Explained (AVE) according to the acceptable index should be higher than the value of squared correlations between the latent variables and all other variables. The discriminant validity is confirmed (Table 2) as the value of AVE's square root is greater than the inter-construct correlations coefficient (Hair et al., 2006). Additionally, the discriminant validity existed when there was a low correlation between each variable measurement indicator with all other variables except with the one with which it must be theoretically associated (Aggarwal et al., 2018a, b; Aggarwal et al., 2020). The results of Table 2 show that the measurement model achieved good discriminate validity.

\subsection{Structural model}

To test the proposed hypothesis, the researcher used the structural equation modeling technique. This is a multivariate statistical analysis technique, and it includes the amalgamation of factor analysis and multiple regression analysis. It is used to analyze the structural relationship between measured variables and latent constructs.

Table 3 represents the structural model's model fitness indices where all variables put together when CMIN/DF is 2.479, and all the model fit values are within the particular range. That means the model has attained a good model fit. Furthermore, other fit indices as GFI $=.982$ and AGFI $=0.956$ be all so supportive (Schumacker \& Lomax, 1996; Marsh \& Grayson, 1995; Kline, 2005).

Table 3 Criterion for model fit

\begin{tabular}{lll}
\hline $\begin{array}{l}\text { Criterion for goodness of fit } \\
\text { measure }\end{array}$ & $\begin{array}{l}\text { Recommended } \\
\text { values }\end{array}$ & Model fit value \\
\hline CMIN/DF & $\geq 3$ & 2.479 \\
GFI & $>0.90$ & .982 \\
AGFI & $>0.80$ & .956 \\
RMR & $\leq 0.08$ & .040 \\
RMSEA & $\leq 0.08$ & .052 \\
\hline
\end{tabular}

Author's compilation 
Hence, the model fitted the data successfully. All co-variances among the variables and regression weights were statistically significant $(p<0.001)$.

Table 4 represents the relationship between exogenous, mediator and endogenous variables viz-quality of instructor, prompt feedback, course design, students' expectation, students' satisfaction and students' performance. The first four factors have a positive relationship with satisfaction, which further leads to students' performance positively. Results show that the instructor's quality has a positive relationship with the satisfaction of students for online classes $(\mathrm{SE}=0.706$, $\mathrm{t}$-value $=24.196$; $p<0.05)$. Hence, $\mathrm{H} 1$ was supported. The second factor is course design, which has a positive relationship with students' satisfaction of students ( $\mathrm{SE}=0.064$, $\mathrm{t}$-value $=2.395 ; \mathrm{p}<0.05)$. Hence, $\mathrm{H} 2$ was supported. The third factor is Prompt feedback, and results show that feedback has a positive relationship with the satisfaction of the students $(\mathrm{SE}=0.067, \mathrm{t}$-value $=2.520 ; \mathrm{p}<0.05)$. Hence, H3 was supported. The fourth factor is students' expectations. The results show a positive relationship between students' expectation and students' satisfaction with online classes $(\mathrm{SE}=0.149$, $\mathrm{t}-\mathrm{value}=5.127 ; \mathrm{p}<0.05)$. Hence, $\mathrm{H} 4$ was supported. The results of SEM show that out of quality of instructor, prompt feedback, course design, and students' expectation, the most influencing factor that affect the students' satisfaction was instructor's quality ( $\mathrm{SE}=0.706$ ) followed by students' expectation ( $\mathrm{SE}=5.127$ ), prompt feedback $(\mathrm{SE}=2.520)$. The factor that least affects the students' satisfaction was course design (2.395). The results of Table 4 finally depicts that students' satisfaction has positive effect on students' performance ( $(\mathrm{SE}=0.186, \mathrm{t}$-value $=2.800$; $\mathrm{p}<0.05)$. Hence H5 was supported.

Table 5 shows that students' satisfaction partially mediates the positive relationship between the instructor's quality and student performance. Hence, H6(a) was supported. Further, the mediation analysis results showed that satisfaction again partially mediates the positive relationship between course design and student's performance. Hence, H6(b) was supported However, the mediation analysis results showed that satisfaction fully mediates the positive relationship between prompt feedback and student performance. Hence, H6(c) was supported. Finally, the results of the Table 5 showed that satisfaction partially mediates the positive relationship between expectations of the students and student's performance. Hence, H6(d) was supported.

Table 4 Structural analysis

\begin{tabular}{|c|c|c|c|c|c|c|c|}
\hline Hypothesis & Relationship & & & $\begin{array}{l}\text { Standardized } \\
\text { Estimate (SE) }\end{array}$ & C.R. & $p$ value & Decision \\
\hline $\mathrm{H} 1(+)$ & Satisfaction & $<--$ & $\begin{array}{l}\text { Quality of the Instruc- } \\
\text { tor }\end{array}$ & 0.706 & 24.196 & $* * *$ & Supported \\
\hline $\mathrm{H} 2(+)$ & Satisfaction & $<--$ & Course Design & 0.064 & 2.395 & 0.017 & Supported \\
\hline $\mathrm{H} 3(+)$ & Satisfaction & $<--$ & Prompt Feedback & 0.067 & 2.520 & 0.012 & Supported \\
\hline $\mathrm{H} 4(+)$ & Satisfaction & $<---$ & Expectation of Student & 0.149 & 5.127 & $* * *$ & Supported \\
\hline $\mathrm{H} 5(+)$ & Performance & $<---$ & Satisfaction & 0.186 & 2.800 & 0.005 & Supported \\
\hline
\end{tabular}

Author's Compilation 


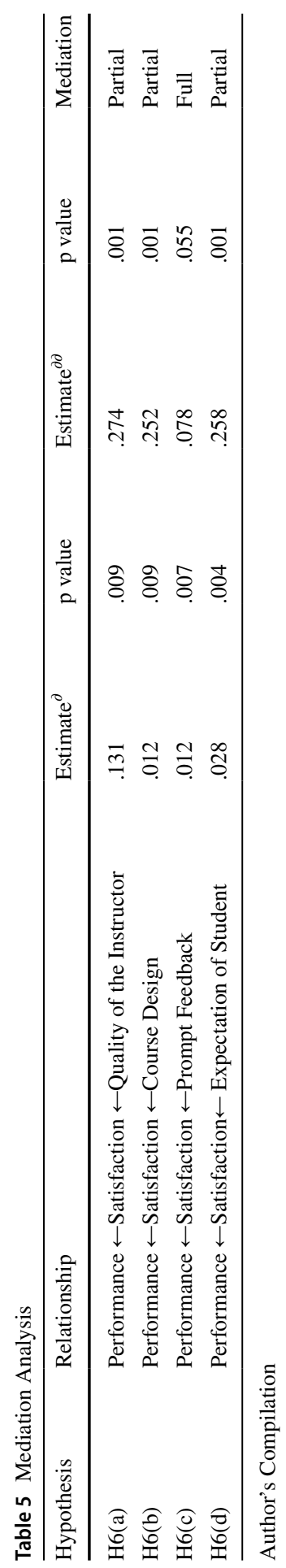




\section{Discussion}

In the present study, the authors evaluated the different factors directly linked with students' satisfaction and performance with online classes during Covid19. Due to the pandemic situation globally, all the colleges and universities were shifted to online mode by their respective governments. No one has the information that how long this pandemic will remain, and hence the teaching method was shifted to online mode. Even though some of the educators were not tech-savvy, they updated themselves to battle the unexpected circumstance (Pillai et al., 2021). The present study results will help the educators increase the student's satisfaction and performance in online classes. The current research assists educators in understanding the different factors that are required for online teaching.

Comparing the current research with past studies, the past studies have examined the factors affecting the student's satisfaction in the conventional schooling framework. However, the present study was conducted during India's lockdown period to identify the prominent factors that derive the student's satisfaction with online classes. The study also explored the direct linkage between student's satisfaction and their performance. The present study's findings indicated that instructor's quality is the most prominent factor that affects the student's satisfaction during online classes. This means that the instructor needs to be very efficient during the lectures. He needs to understand students' psychology to deliver the course content prominently. If the teacher can deliver the course content properly, it affects the student's satisfaction and performance. The teachers' perspective is critical because their enthusiasm leads to a better online learning process quality.

The present study highlighted that the second most prominent factor affecting students' satisfaction during online classes is the student's expectations. Students might have some expectations during the classes. If the instructor understands that expectation and customizes his/her course design following the student's expectations, then it is expected that the students will perform better in the examinations. The third factor that affects the student's satisfaction is feedback. After delivering the course, appropriate feedback should be taken by the instructors to plan future courses. It also helps to make the future strategies (Tawafak et al., 2019). There must be a proper feedback system for improvement because feedback is the course content's real image. The last factor that affects the student's satisfaction is design. The course content needs to be designed in an effective manner so that students should easily understand it. If the instructor plans the course, so the students understand the content without any problems it effectively leads to satisfaction, and the student can perform better in the exams. In some situations, the course content is difficult to deliver in online teaching like the practical part i.e. recipes of dishes or practical demonstration in the lab. In such a situation, the instructor needs to be more creative in designing and delivering the course content so that it positively impacts the students' overall satisfaction with online classes. 
Overall, the students agreed that online teaching was valuable for them even though the online mode of classes was the first experience during the pandemic period of Covid-19 (Agarwal \& Kaushik, 2020; Rajabalee \& Santally, 2020). Some of the previous studies suggest that the technology-supported courses have a positive relationship with students' performance (Cho \& Schelzer, 2000; Harasim, 2000; Sigala, 2002). On the other hand, the demographic characteristic also plays a vital role in understanding the online course performance. According to APA Work Group of the Board of Educational Affairs (1997), the learner-centered principles suggest that students must be willing to invest the time required to complete individual course assignments. Online instructors must be enthusiastic about developing genuine instructional resources that actively connect learners and encourage them toward proficient performances. For better performance in studies, both teachers and students have equal responsibility. When the learner faces any problem to understand the concepts, he needs to make inquiries for the instructor's solutions (Bangert, 2004). Thus, we can conclude that "instructor quality, student's expectation, prompt feedback, and effective course design" significantly impact students' online learning process.

\section{Implications of the study}

The results of this study have numerous significant practical implications for educators, students and researchers. It also contributes to the literature by demonstrating that multiple factors are responsible for student satisfaction and performance in the context of online classes during the period of the COVID-19 pandemic. This study was different from the previous studies (Baber, 2020; Ikhsan et al., 2019; Eom \& Ashill, 2016). None of the studies had examined the effect of students' satisfaction on their perceived academic performance. The previous empirical findings have highlighted the importance of examining the factors affecting student satisfaction (Maqableh \& Jaradat, 2021; Yunusa \& Umar, 2021). Still, none of the studies has examined the effect of course design, quality of instructor, prompt feedback, and students' expectations on students' satisfaction all together with online classes during the pandemic period. The present study tries to fill this research gap.

The first essential contribution of this study was the instructor's facilitating role, and the competence he/she possesses affects the level of satisfaction of the students (Gray \& DiLoreto, 2016). There was an extra obligation for instructors who taught online courses during the pandemic. They would have to adapt to a changing climate, polish their technical skills throughout the process, and foster new students' technical knowledge in this environment. The present study's findings indicate that instructor quality is a significant determinant of student satisfaction during online classes amid a pandemic. In higher education, the teacher's standard referred to the instructor's specific individual characteristics before entering the class (Darling-Hammond, 2010). These attributes include factors such as instructor content knowledge, pedagogical knowledge, inclination, and experience. More significantly, at that level, the amount of understanding could be given by those who have a significant amount of technical expertise 
in the areas they are teaching (Martin, 2021). Secondly, the present study results contribute to the profession of education by illustrating a realistic approach that can be used to recognize students' expectations in their class effectively. The primary expectation of most students before joining a university is employment. Instructors have agreed that they should do more to fulfill students' employment expectations (Gorgodze et al., 2020). The instructor can then use that to balance expectations to improve student satisfaction. Study results can be used to continually improve and build courses, as well as to make policy decisions to improve education programs. Thirdly, from result outcomes, online course design and instructors will delve deeper into how to structure online courses more efficiently, including design features that minimize adversely and maximize optimistic emotion, contributing to greater student satisfaction (Martin et al., 2018). The findings suggest that the course design has a substantial positive influence on the online class's student performance. The findings indicate that the course design of online classes need to provide essential details like course content, educational goals, course structure, and course output in a consistent manner so that students would find the e-learning system beneficial for them; this situation will enable students to use the system and that leads to student performance (Almaiah \& Alyoussef, 2019). Lastly, the results indicate that instructors respond to questions promptly and provide timely feedback on assignments to facilitate techniques that help students in online courses improve instructor participation, instructor interaction, understanding, and participation (Martin et al., 2018). Feedback can be beneficial for students to focus on the performance that enhances their learning.

\section{Limitations and future scope of the study}

The data collected in this study was cross-sectional in nature due to which it is difficult to establish the causal relationship between the variables. The future research can use a longitudinal study to handle this limitation. Further, the data was collected from one type of respondents only, that is, the students. Therefore, the results of the study cannot be generalized to other samples. The future research can also include the perspectives of teachers and policy makers to have more generalization of the results. The current research is only limited to theory classes; therefore, it can be implemented to check students' performance in practical classes. The study is done on the Indian students only; thus, if the data is collected from various countries, it can give better comparative results to understand the student's perspective. This study is limited to check the performance of students, so in the future, the performance of teachers can be checked with similar kinds of conditions. There may be some issues and problems faced by the students, like the limited access to the internet or disturbance due to low signals. Some of the students may face the home environment issues such as disturbance due to family members, which may lead to negative performance. The above-mentioned points can be inculcated in the future research. 


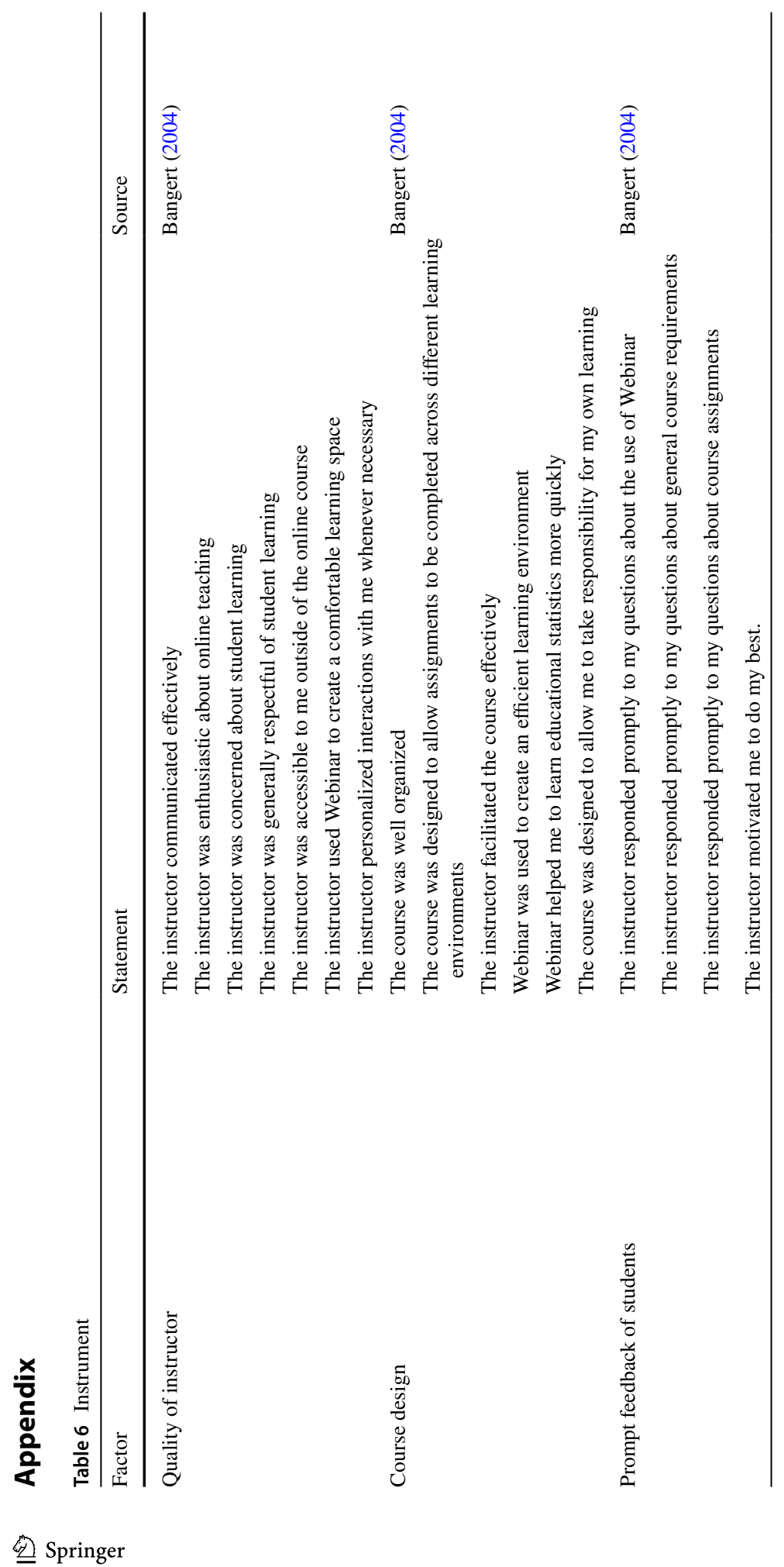




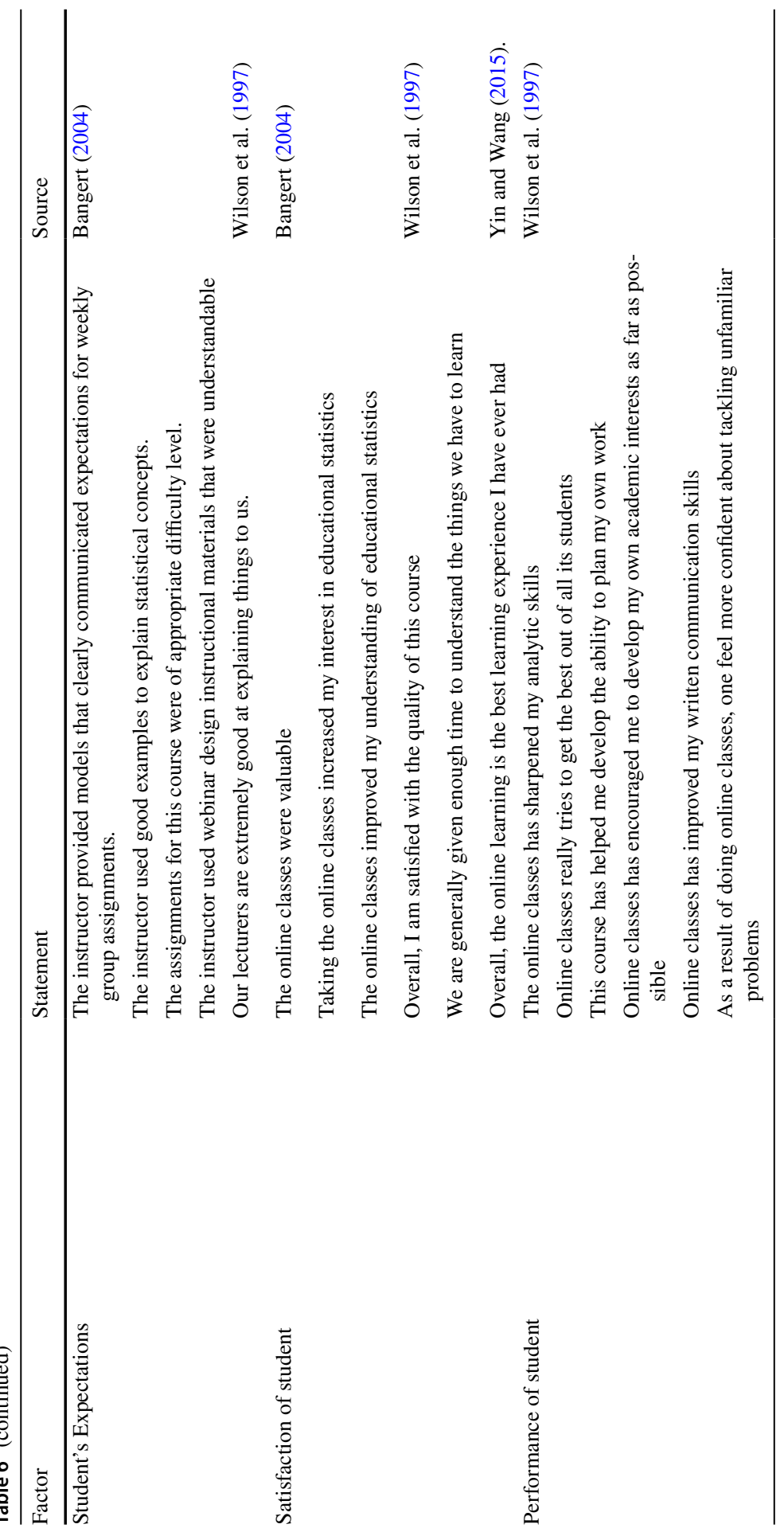




\section{Declarations}

Ethics approval Not applicable.

Conflict of interest The authors declare no conflict of interest, financial or otherwise.

\section{References}

Agarwal, S., \& Kaushik, J. S. (2020). Student's perception of online learning during COVID pandemic. The Indian Journal of Pediatrics, 87, 554-554.

Aggarwal, A., Dhaliwal, R. S., \& Nobi, K. (2018a). Impact of structural empowerment on organizational commitment: The mediating role of women's psychological empowerment. Vision, 22(3), 284-294.

Aggarwal, A., Goyal, J., \& Nobi, K. (2018b). Examining the impact of leader-member exchange on perceptions of organizational justice: The mediating role of perceptions of organizational politics. Theoretical Economics Letters, 8(11), 2308-2329.

Aggarwal, A., Chand, P. A., Jhamb, D., \& Mittal, A. (2020). Leader-member exchange, work engagement and psychological withdrawal behaviour: The mediating role of psychological empowerment. Frontiers in Psychology, 11, 1-17.

Almaiah, M. A., \& Almulhem, A. (2018). A conceptual framework for determining the success factors of e-learning system implementation using Delphi technique. Journal of Theoretical and Applied Information Technology, 96(17), 5962-5976.

Almaiah, M. A., \& Alyoussef, I. Y. (2019). Analysis of the effect of course design, course content support, course assessment and instructor characteristics on the actual use of E-learning system. Ieee Access, 7, 171907-171922.

Ames, C. (1992). Classrooms: Goals, structures, and student motivation. Journal of Educational Psychology, 84, 261-271.

Ames, C., \& Archer, J. (1988). Achievement goals in the classroom: Student's learning strategies and motivational processes. Journal of Educational Psychology, 80, 260-267.

APA Work Group of the Board of Educational Affairs. (1997). Learner-centered psychological principles: A framework for school reform and redesign. American Psychological Association.

Appleton-Knapp, S., \& Krentler, K. A. (2006). Measuring student expectations and their effects on satisfaction: The importance of managing student expectations. Journal of Marketing Education, 28(3), 254-264.

Arambewela, R., \& Hall, J. (2009). An empirical model of international student satisfaction. Asia Pacific Journal of Marketing and Logistics, 21(4), 555-569.

Azlan, A. A., Hamzah, M. R., Sern, T. J., Ayub, S. H., \& Mohamad, E. (2020). Public knowledge, attitudes and practices towards COVID-19: A cross-sectional study in Malaysia. PLoS One, 15(5), $\mathrm{e} 0233668$.

Baber, H. (2020). Determinants of Students' perceived outcome and satisfaction in online learning during the pandemic of COVID-19. Journal of Education and e-Learning Research, 7(3), 285-292.

Bangert, A. W. (2004). The seven principles of good practice: A framework for evaluating on- line teaching. The Internet and Higher Education, 7(3), 217-232.

Bates, E. A., \& Kaye, L. K. (2014). "I'd be expecting caviar in lectures": The impact of the new fee regime on undergraduate students' expectations of higher education. Higher Education, 67(5), $655-673$.

Bayham, J., \& Fenichel, E.P. (2020). The impact of school closure for COVID-19 on the US healthcare workforce and the net mortality effects. Available at SSRN: https://doi.org/10.2139/ssrn.3555259.

Bersin, J. (2004). The blended learning book: Best practices, proven methodologies and lessons learned. Pfeiffer Publishing.

Biner, P. M., Summers, M., Dean, R. S., Bink, M. L., Anderson, J. L., \& Gelder, B. C. (1996). Student satisfaction with interactive telecourses as a function of demographic variables and prior telecourse experience. Distance Education., 17(11), 33-43.

Black, G. S., \& Kassaye, W. W. (2014). Do students learning styles impact student outcomes in marketing classes? Academy of Educational Leadership Journal, 18(4), 149-162. 
Bridge, S. (2020). Opinion: How edtech will keep our students on track during covid-19. Arabian business. Com Retrieved from https://search.proquest.com/docview/2377556452?accountid= 147490. Accessed 12 Oct 2020.

Brown, S. A., Venkatesh, V., \& Goyal, S. (2014). Expectation confirmation in information systems research: A test of six competing models. MIS Quarterly, 38(3), 729-756.

Brownlee, J., Walker, S., Lennox, S., Exley, B., \& Pearce, S. (2009). The first year university experience: Using personal epistemology to understsnd effective learning and teaching in higher education. Higher Education, 58(5), 599-618.

Budur, T., Faraj, K. M., \& Karim, L. A. (2019). Benchmarking operations strategies via hybrid model: A case study of café-restaurant sector. Amozonia Investiga, 8, 842-854.

Centers for Disease Control and Prevention (2020). Coronavirus disease 2019 (COVID-19): Reducing stigma. Retrieved November 26, 2020, from: https://www.cdc.gov/coronavirus/2019-ncov/about/ related-stigma.html.

Chang, N. (2011). Pre-service Teachers' views: How did E-feedback through assessment facilitate their learning? Journal of the Scholarship of Teaching and Learning, 11(2), 16-33.

Chickering, A. W., \& Gamson, Z. F. (1987). Seven principles for good practice in undergraduate education. AAHE Bulletin, 39(7), 3-7.

Cho, W., \& Schelzer, C. (2000). Just in-time education: Tools for hospitality managers of the future? International Journal of Contemporary Hospitality Management, 12(1), 31-36.

Christensen, A. L. (2014). Feedback, affect, and creative behavior: A multi-level model linking feedback to performance. Arizona State University.

Clayton, K., Blumberg, F., \& Auld, D. P. (2010). The relationship between motivation, learning strategies and choice of environment whether traditional or including an online component. British Journal of Educational Technology, 41(3), 349-364.

Darling-Hammond, L. (2010). Evaluating teacher effectiveness: How teacher performance assessments can measure and improve teaching. Washington, DC: Center for American Progress

DeBourgh, G. A. (2003). Predictors of student satisfaction in distance-delivered graduate nursing courses: What matters most? Journal of Professional Nursing, 19, 149-163.

Dweck, C., \& Leggett, E. (1988). A social-cognitive approach to motivation and personality. Psychological Review, 95, 256-273.

Elliot, A. J. (2005). A conceptual history of the achievement goal construct. In A. Elliot \& C. Dweck (Eds.), Handbook of competence and motivation (pp. 52-72). Guilford Press.

Elliot, A., \& McGregor, H. (2001). A 2 _ 2 achievement goal framework. Journal of Personality and Social Psychology, 80, 501-519.

Elliott, E. S., \& Dweck, C. S. (1988). Goals: An approach to motivation and achievement. Journal of Personality and Social Psychology, 54(1), 5.

Eom, S. B., \& Ashill, N. (2016). The determinants of students' perceived learning outcomes and satisfaction in university online education: An update. Decision Sciences Journal of Innovative Education, 14(2), 185-215.

Eraut, M., (2006). Feedback. Learning in Health and Social Care. Volume-5, issue-3. Pg 111-118. Retrieved from https://edservices.wiley.com/how-student-feedback-creates-better-online- learn ing/. Accessed 23 Oct 2020.

Farooq, M. S., Chaudhry, A. H., Shafiq, M., \& Berhanu, G. (2011). Factors affecting students' quality of academic performance: A case of secondary school level. Journal of Quality and Technology Management, 7, 1-14.

Fredericksen, E., Shea, P., \& Pickett, A. (2000). Factors influencing student and faculty satisfaction in the SUNY learning network. State University of New York.

Gold, S. (2011). A constructivist approach to online training for online teachers. Journal of Aysnchronous Learning Networks, 5(1), 35-57.

González-Gómez, D., Jeong, J. S., \& Rodríguez, D. A. (2016). Performance and perception in the flipped learning model: An initial approach to evaluate the effectiveness of a new teaching methodology in a general science classroom. Journal of Science Education and Technology, 25(3), 450-459.

Gorgodze, S., Macharashvili, L., \& Kamladze, A. (2020). Learning for earning: Student expectations and perceptions of university. International Education Studies, 13(1), 42-53.

Grammatikopoulos, V., Linardakis, M., Gregoriadis, A., \& Oikonomidis, V. (2014). Assessing the Students' evaluations of educational quality (SEEQ) questionnaire in Greek higher education. Higher Education., 70(3). 
Gray, J. A., \& DiLoreto, M. (2016). The effects of student engagement, student satisfaction, and perceived learning in online learning environments. International Journal of Educational Leadership Preparation, 11(1), n1.

Grebennikov, L., \& Shah, S. (2013). Monitoring trends in student satisfaction. Tertiary Education and Management, 19(4), 301-322.

Hair, J. F., Black, W. C., Babin, B. J., Anderson, R. E., \& Tatham, R. L. (2006). Multivariate data analysis 6th edition. Pearson Prentice Hall. New Jersey. Humans: Critique and reformulation. Journal of Abnormal Psychology, 87, 49-74.

Hansen, G., \& Ringdal, R. (2018). Formative assessment as a future step in maintaining the masteryapproach and performance-avoidance goal stability. Studies in Educational Evaluation, 56, 59-70.

Harasim, L. (2000). Shift happens: Online education as a new paradigm in learning. The Internet and Higher Education, 3(1), 41-61.

Hattie, J., \& Timperley, H. (2007). The power of feedback. Review of Educational Research, 77(1), 81-112.

Henriksen, D., Creely, E., \& Henderson, M. (2020). Folk pedagogies for teacher transitions: Approaches to synchronous online learning in the wake of COVID-19. Journal of Technology and Teacher Education, 28(2), 201-209.

Ho, A., Lu, L., \& Thurmaier, K. (2006). Testing the reluctant Professor's hypothesis: Evaluating a blended-learning approach to distance education. Journal of Public Affairs Education, 12(1), 81-102.

ICSB (2015). Addressing undergraduate entrepreneurship student expectations: An exploratory study. International Council for Small Business (ICSB). Retrieved from https://search.proquest.com/docvi ew/1826918813?accountid=147490. Accessed 20 Oct 2020.

Ikhsan, R. B., Saraswati, L. A., Muchardie, B. G., \& Susilo, A. (2019). The determinants of students' perceived learning outcomes and satisfaction in BINUS online learning. Paper presented at the 2019 5th International Conference on New Media Studies (CONMEDIA). IEEE.

Jenkins, D. M. (2015). Integrated course design: A facelift for college courses. Journal of Management Education, 39(3), 427-432.

Kauffman, H. (2015). A review of predictive factors of student success in and satisfaction with online learning. Research in Learning Technology, 23.

Khan, N. U. S., \& Yildiz, Y. (2020). Impact of intangible characteristics of universities on student satisfaction. Amazonia Investiga, 9(26), 105-116.

Kinicki, A. J., Prussia, G. E., Wu, B. J., \& McKee-Ryan, F. M. (2004). A covariance structure analysis of employees' response to performance feedback. Journal of Applied Psychology, 89(6), 1057-1069.

Kline, R. B. (2005). Principles and practice of structural equation modeling (2nd ed.). The Guilford Press.

Kotler, P., \& Clarke, R. N. (1986). Marketing for health care organizations. Prentice Hall.

Lado, N., Cardone-Riportella, C., \& Rivera-Torres, P. (2003). Measurement and effects of teaching quality: An empirical model applied to masters programs. Journal of Business Education, 4, 28-40.

Ladyshewsky, R. K. (2013). Instructor presence in online courses and student satisfaction. International Journal for the Scholarship of Teaching and Learning., 7, 1.

Lah, K., \& G. Botelho. (2012). Union Opts to Continue Chicago Teachers Strike; Mayor Takes Fight to Court. http://articles.cnn.com/2012-09-16/us/us_illinois-chicago-teachersstrike_1_chicago-teach ers-union-union-president-karen-lewis-union-delegates.

Lee, J. (2014). An exploratory study of effective online learning: Assessing satisfaction levels of graduate students of mathematics education associated with human and design factors of an online course. The International Review of Research in Open and Distance Learning, 15(1), 111-132.

Liaw, S.-S. (2008). Investigating students' perceived satisfaction, behavioral intention, and effectiveness of e-learning: A case study of the blackboard system. Computers \& Education, 51(2), 864-873.

Lin, Y., Lin, G., \& Laffey, J. M. (2008). Building a social and motivational framework for understanding satisfaction in online learning. Journal of Educational Computing Research, 38(1), 1-27.

Lockman, A. S., \& Schirmer, B. R. (2020). Online instruction in higher education: Promising, researchbased, and evidence-based practices. Journal of Education and e-Learning Research, 7(2), $130-152$.

Luekens, M.T., Lyter, D.M., and Fox, E.E. (2004). Teacher attrition and mobility: Results from the teacher follow-up survey, 2000-01 (NCES 2004-301). National Center for Education Statistics, U.S. Department of Education. Washington, DC. https://nces.ed.gov/pubsearch/pubsinfo.asp? pubid=2004301. 
Malik, M. E., Danish, R. Q., \& Usman, A. (2010). The impact of service quality on students' satisfaction in higher education institutes of Punjab. Journal of Management Research, 2(2), 1-11.

Maqableh, M., \& Jaradat, M. (2021). Exploring the determinants of students' academic performance at university level: The mediating role of internet usage continuance intention. Education and Information Technologies. https://doi.org/10.1007/s10639-021-10453-y.

Marsh, H. W. (1987). Students' evaluations of university teaching: Research findings, methodological issues, and directions for future research. International Journal of Educational Research, 11, 253-388.

Marsh, H. W., \& Grayson, D. (1995). Latent variable models of multitrait-multimethod data.Marsh, H. W., \& Grayson, D. (1995). Latent variable models of multitrait-multimethod data. In R. H. Hoyle (Ed.), Structural equation modeling: Concepts, issues, and applications (p. 177-198). Sage Publications, Inc.

Martin, A. M. (2021). Instructor qualities and student success in higher education online courses. Journal of Digital Learning in Teacher Education, 37(1), 65-80.

Martínez-Argüelles, M. J., \& Batalla-Busquets, J. M. (2016). Perceived service quality and student loyalty in an online university. International Review of Research in Open and Distributed Learning, 17(4), 264-279.

Martin, F., Wang, C., \& Sadaf, A. (2018). Student perception of helpfulness of facilitation strategies that enhance instructor presence, connectedness, engagement, and learning in online courses. The Internet and Higher Education, 37, 52-65.

Mensink, P. J., \& King, K. (2020). Student access of online feedback is modified by the availability of assessment marks, gender and academic performance. British Journal of Educational Technology, 51(1), 10-22.

Mohammed, S. S., Suleyman, C., \& Taylan, B. (2020). Burnout determinants and consequences among university lecturers. Amazonia Investiga, 9(27), 13-24.

Moore, J. L., Dickson-Deane, C., \& Galyen, K. (2011). E-learning, online learning, and distance learning environments: Are they the same? Internet Higher Educ, 14(2), 129-135.

Mouratidis, A., Michou, A., Demircioğlu, A. N., \& Sayil, M. (2018). Different goals, different pathways to success: Performance-approach goals as direct and mastery-approach goals as indirect predictors of grades in mathematics. Learning and Individual Differences, 61, 127-135.

Mtebe, J. S., \& Raisamo, R. (2014). A model for assessing learning management system success in higher education in sub-Saharan countries. The Electronic Journal of Information Systems in Developing Countries, 61(1), 1-17.

Munteanu, C., Ceobanu, C., Bobâlca, C., \& Anton, O. (2010). An analysis of customer satisfaction in a higher education context. The International Journal of Public Sector Management, 23(2), 124.

Narad, A., \& Abdullah, B. (2016). Academic performance of senior secondary school students: Influence of parental encouragement and school environment. Rupkatha Journal on Interdisciplinary Studies in Humanities, 8(2), 12-19.

NDTV (2020). Schools Closed, Travel To Be Avoided, Says Centre On Coronavirus: 10 Points. NDTV. com. Retrieved March 18, 2020.

O'donovan, B. (2017). How student beliefs about knowledge and knowing influence their satisfaction with assessment and feedback. Higher Education, 74(4), 617-633.

Oliver, R. L. (1980). A congitive model of the antecedents and consequences of satisfaction decisions. JMR, Journal of Marketing Research (Pre-1986), 17(000004), 460.

Pei, L., \& Wu, H. (2019). Does online learning work better than offline learning in undergraduate medical education? A systematic review and meta-analysis. Medical Education Online, 24(1), 1666538.

Perlman S, \& Mclntosh K. (2020). Coronaviruses, including severe acute respiratory syndrome (SARS) and Middle East respiratory syndrome (MERS). In: J.E Benett, R. Dolin, M. J. Blaser (Eds.), Mandell, Douglas, and Bennett's principles and practice of infectious diseases. 9th ed. Philadelphia, PA: Elsevier: chap 155.

Pillai, K. R., Upadhyaya, P., Prakash, A. V., Ramaprasad, B. S., Mukesh, H. V., \& Pai, Y. (2021). Enduser satisfaction of technology-enabled assessment in higher education: A coping theory perspective. Education and Information Technologies. https://doi.org/10.1007/s10639-020-10401-2.

Pintrich, P. (1999). The role of motivation in promoting and sustaining self-regulated learning. International Journal of Educational Research, 31, 459-470.

Rajabalee, Y. B., \& Santally, M. I. (2020). Learner satisfaction, engagement and performances in an online module: Implications for institutional e-learning policy. Education and Information Technologies. https://doi.org/10.1007/s10639-020-10375-1. 
Ramsden, P. A. (1991). Performance indicator of teaching quality in higher education: The course experience questionnaire. Studies in Higher Education, 16(2), 129-150.

Rogers, J. (1992). Adults learning (3rd ed.). Open University Press.

Rono, R. (2013). Factors affecting pupils' performance in public primary schools at Kenya certificate of primary education examination (Kcpe) in Emgwen Division, Nandi District, Kenya (Doctoral dissertation, University of Nairobi).

Salloum, S. A. and Shaalan, K. (2018). Investigating students' acceptance of e-learning system in higher educational environments in the UAE: Applying the extended technology acceptance model (TAM), Ph.D. dissertation, Brit. Univ. Dubai, Dubai, United Arab Emirates, 2018.

Sanderson, G. (1995). Objectives and evaluation. In S. Truelove (Ed.), Handbook of training and development (2nd ed., pp. 113-144). Blackwell.

Schumacker, R. E., \& Lomax, R. G. (1996). A beginner's guide to structural equation modeling. L. L. Erlbaum Associates.

Schwarz, C., \& Zhu, Z. (2015). The impact of student expectations in using instructional tools on student engagement: A look through the expectation disconfirmation theory lens. Journal of Information Systems Education, 26(1), 47-58.

Schwinger, M., \& Stiensmeier-Pelster, J. (2011). Performance-approach and performance-avoidance classroom goals and the adoption of personal achievement goals. British Journal of Educational Psychology, 81(4), 680-699.

Sher, A. (2009). Assessing the relationship of student-instructor and student-student interaction to student learning and satisfaction in web-based online learning environment. Journal of Interactive Online Learning, 8(2).

Sibanda, L., Iwu, C. G., \& Benedict, O. H. (2015). Factors influencing academic performance of university students. Демографія та соиіальна економіка, 2, 103-115.

Sigala, M. (2002). The evolution of internet pedagogy: Benefits for tourism and hospitality education. Journal of Hospitality, Leisure Sport and Tourism Education, 1(2), 29-45.

Simsek, U., Turan, I., \& Simsek, U. (2017). Social studies teachers" and teacher candidates" perceptions on prompt feedback and communicate high expectations. PEOPLE: International Journal of Social Sciences, 3(1), 332, 345.

Singh, S. P., Malik, S., \& Singh, P. (2016). Factors affecting academic performance of students. ParipexIndian Journal of Research, 5(4), 176-178.

Shehzadi, S., Nisar, Q. A., Hussain, M. S., Basheer, M. F., Hameed, W. U., \& Chaudhry, N. I. (2020). The role of digital learning toward students' satisfaction and university brand image at educational institutes of Pakistan: a post-effect of COVID-19. Asian Education and Development Studies, 10(2), 276-294.

Tawafak, R. M., Romli, A. B., \& Alsinani, M. (2019). E-learning system of UCOM for improving student assessment feedback in Oman higher education. Education and Information Technologies, 24(2), 1311-1335.

UNESCO (2020). United nations educational, scientific and cultural organization. COVID19 educational disruption and response. UNESCO, Paris, France. https://en.unesco.org/themes/education-emerg encies/coronavirus-school-closures. Accessed 17 Nov 2020.

Urdan, T. (1997). Achievement goal theory: Past results, future directions. Advances in Motivation and Achievement, 10, 99-141.

Wilson, K. L., Lizzio, A., \& Ramsden, P. (1997). The development, validation and application of the course experience questionnaire. Studies in Higher Education, 22(1), 33-53.

Wooldridge, B. (1995). Increasing the effectiveness of university/college instruction: Integrating the results of learning style research into course design and delivery. In R. R. Simms and S. J. Simms (Eds.), the Importance of Learning Styles. Westport, CT: Greenwood Press, 49-67.

World Health Organization (2019). https://www.who.int/health-topics/coronavirus\#tab=tab_1, Retrieved 29 March 2020.

Wright, C. R. (2003). Criteria for evaluating the quality of online courses. Alberta distance Educ. Training Assoc., 16(2), 185-200.

Yen, S. C., Lo, Y., Lee, A., \& Enriquez, J. (2018). Learning online, offline, and in-between: Comparing student academic outcomes and course satisfaction in face-to-face, online, and blended teaching modalities. Education and Information Technologies, 23(5), 2141-2153.

Yin, H., \& Wang, W. (2015). Assessing and improving the quality of undergraduate teaching in China: The course experience questionnaire. Assessment \& Evaluation in Higher Education, 40(8), 1032-1049. 
Yorke, M. (2003). Formative assessment in higher education: Moves towards theory and the enhancement of pedagogic practice. Higher Education, 45(4), 477-501.

Yu, F., Du, L., Ojcius, D. M., Pan, C., \& Jiang, S. (2020). Measures for diagnosing and treating infections by a novel coronavirus responsible for a pneumonia outbreak originating in Wuhan, China. Microbes and Infection, 22(2), 74-79.

Yunusa, A. A., \& Umar, I. N. (2021). A scoping review of critical predictive factors (CPFs) of satisfaction and perceived learning outcomes in E-learning environments. Education and Information Technologies, 26(1), 1223-1270.

Zeithaml, V. A. (1988). Consumer perceptions of price, quality, and value: A means-end model and synthesis of evidence. Journal of Marketing, 52(3), 2-22.

Zhang, L., Han, Z., \& Gao, Q. (2008). Empirical study on the student satisfaction index in higher education. International Journal of Business and Management, 3(9), 46-51.

Publisher's note Springer Nature remains neutral with regard to jurisdictional claims in published maps and institutional affiliations. 